\title{
Impact of the Vietnam - EAEU FTA on the trade between Vietnam and Eurasian Economic Union
}

\author{
Quy Thuan Bui \\ Academy of Policy and Development \\ Hoai Duc, Ha Noi, Vietnam \\ thuanbq@apd.edu.vn
}

\author{
Thanh Cong Ha \\ Faculty of Business Management \\ Hanoi University of Industry, Viet Nam \\ Cau Dien Street, North Tu Liem District, \\ Ha Noi, Viet Nam \\ conght@haui.edu.vn
}

\begin{abstract}
This study uses a structural gravity model of trade to examine the impact of the Vietnam - Eurasian Economic Union free trade agreement (FTA Vietnam - EAEU) on exports and imports between Vietnam and its member countries before and after the agreement. The model is tested on a sample of industry-level panel data from 2001 to 2019 , the author estimates the fixed-effects model (FEM) in the country - paired with the number of observations obtained is 5,386 observations forming a repeat sample, unbalanced. The paper also performs Pseudo Poisson maximum likelihood estimation (PPML) is also applied to solve the zero trade issue and the presence of heteroskedasticity. The results indicate that the agreement leads to "trade creation", import and export turnover increases compared to before the agreement. The authors propose that the two sides need to boost to produce and export the comparative advantage products in order to seize preferential treatment from the agreement without affecting competition and complementing each other.
\end{abstract}

Index Terms-FTA, Structural Gravity, Vietnam and EAEU.

\section{INTRODUCTION}

$\mathrm{F}$ REE trade liberalization is the process of reducing and removing tax barriers in international trade, creating opportunities to promote growth, improve productivity through specialization and promote competition. In the context of strong globalization and integration, like many countries in the world, Vietnam has pursued trade liberalization (TL) by joining or forming bilateral or plurilateral trade agreements to achieve the various economic benefits that come from creating trade and expanding markets through removing trade barriers, improving productivity, and attracting foreign investment among member countries.

Cassing [10] assesses the impact of FTAs on Vietnam's trade. The results show that the FTAs have different effects on trade, but the benefit that Vietnam gets from the ASEAN FTAs with China, Japan and Korea is the largest, while the FTAs with Australia and Korea are the largest. New Zealand, India bring less benefits. Industries with high output growth rates such as apparel (32\%), vegetables and fruits $(29 \%)$, leather products $(22 \%)$, transportation and communication services $(15 \%)$, textiles $(14 \%)$, manufactured goods (12\%). Furthermore, looking to the future, the Vietnam-EU FTA provides an opportunity to access a large market that can generate significant benefits [44].

The Eurasian Economic Union (EAEU) is a regional economic union of the Sodrujestvo Nezavisimykh Gosudarstv (SNG) comprising the countries of the former Soviet Union
(Russia, Belarus, Kazakhstan, Armenia, Kyrgystan), in which Russia Countries that play an important role in the alliance are all traditional partners of Vietnam. The EAEU is a market with 180 million people and has a GDP of more than $\$ 1.9$ trillion, but the reality is not as deeply integrated into the global economy as other regions, which makes the EAEU attractive to many trading partners globally and especially in the Asia-Pacific region. Vietnam is considered an important partner of the EAEU countries in this region both politically and economically. Promoting cooperation with Vietnam will create opportunities for EAEU countries to access the ASEAN market. The EAEU is a market for Vietnam's export of agricultural and aquatic products, textiles, footwear, and electronic equipment, as well as a market for low-cost, high-quality energy supplies for Vietnam. The EAEU's selection of Vietnam as the first partner to sign a free trade agreement at the end of 2015 aims to create an open legal corridor, increase the competitiveness of goods, and open up trade flows between the two sides. When this agreement comes into effect, the average tax rate for EAEU goods will be reduced from $10 \%$ to $1 \%$, goods of EAEU members will enjoy the same incentives as other countries on the Vietnamese market [18].

The objective of the article is to assess the impact of the agreement on trade between Vietnam and the EAEU. From the theoretical basis and research review, the author uses the commercial gravity model of [2], [30] with product-level panel data by industry extracted from UNCTAD for the period 2001 to 2019 and estimated the fixed-effects model (FEM) by country pair [7]. The paper also uses the Pseudo Poisson maximum probability estimation method (PPML) to solve the trade data with zero values and the appearance of heteroskedasticity due to [38] proposed.

The article is structured as follows. Section 2 research overview and theoretical background. Section 3 deals with Vietnam Trade and the EAEU. The research model and methodology will be analyzed in Section 4. Section 5 presents experimental research results and discussion. Section 5 will make conclusions and offer some policy implications.

\section{Literature ReView}

Free trade agreements have an economic impact on participating members as well as non-member countries. Viner [43] pointed out the impact of TL on economic restructuring 
stemming from trade creation and trade diversion. Trade creation occurs between member countries by reducing trade barriers. When low-cost imports from a non-member country are replaced by imports from a higher-cost member country because the bloc's members enjoy preferential market access and are not taxed. taxes, trade diversion will occur. Viner [43] also demonstrated that trade diversion makes member countries less efficient in using resources, this effect changes trading partners without increasing welfare and driving production away from benefits. comparative position. Meanwhile, trade creation increases the economic benefits of member countries because it facilitates specialization in production activities through comparative advantage.

Fukao [17] quantitatively analyze the trade diversion effects of NAFTA using HS2 digit level data and using a partial equilibrium framework for industrial products, but the authors are new. Estimates for US imports only. The results show a trade diversion for textiles and some footwear products but no trade diversion for vehicles and television sets.

[47] provide a relative market share index and an increased trade index in FTAs, calculating the volume of trade in goods within the EU and NAFTA (Canada, Mexico and the US) respectively $58.4 \%$ and $43 \%$ in 2005 , the trade flows of ASEAN region also increased from $17 \%$ before AFTA came into effect to $25 \%$ after AFTA came into effect. And at the same time, it has an impact on creating trade in regional free trade agreements such as the North American Free Trade Agreement (NAFTA), the ASEAN Free Trade Area (AFTA), the South American Market Community (MERCOSUR).

[29] show the impact of AFTA and CEPT related to tax reduction leading to trade promotion of ASEAN members. [9] also points out that in addition to the trade creation effect there is also a trade displacement effect that manifests as an increase in intra-regional trade which is completely replaced by a corresponding decrease in imports from the rest of the world.

In addition, the FTA affects the economic restructuring and the distribution of production resources in the economy [26], the reduction of trade barriers brings opportunities for the developing countries to promote economic growth and economic restructuring towards promoting advantageous sectors [19]. FTAs also have a positive effect on industries that promote exports and hinder the development of importprotective industries [37]. The impact of trade liberalization promotes economic restructuring and resource allocation of each member country in the implementation of FTAs [6]. Sectors in the economy always have uneven growth under the impact of FTAs, leading to shifts and changes in the economic structure of industries. Therefore, all countries seek to promote the competitiveness and growth of industries with comparative advantage and narrow down industries without advantages on the basis of allocating and shifting resources to other countries. sectors can be effective [5]. Although FTAs are recognized to have positive effects on trade for member countries, the economic benefits achieved by countries are not entirely the same [11].
Krugman [20] emphasizes that countries with small economies are vulnerable to the effects of international trade. In addition, the benefits of FTAs are also affected by the difference in the export structure of FTA partner countries and other partner countries, especially key partner countries. If the export structure of these two groups of countries is significantly different, the possibility of trade deviation will be reduced, thereby increasing social welfare for FTA member countries [40]. The impact of the agreement on economic benefits, welfare as well as trade in goods in general or some industries with comparative advantages such as industry, agriculture... of a country. However, the degree of impact of FTAs on the economy and competitive industries is different for each country and in different stages of economic development. Vietnam and Russia are comprehensive strategic partners, both members of the Vietnam - EAEU FTA, to assess the impact of this agreement on the trade of the two sides to proactively identify advantages and guide policy. trade to take advantage of the benefits and promote economic growth of each country.

Studies assessing the impact of free trade agreements on Vietnam's economy are based on a posteriori approach, using econometric models such as [33], [3]. Ramstetter \& Phan [36] studied the impact of economic integration and the implementation of FTA commitments in tariff reduction on Vietnam's economic growth, in which in-depth analysis of the shift of a number of sectors in the economy. The impact of international trade and investment on economic restructuring by sectors is also mentioned in the studies of [41]. In addition, the studies mention that the change of bilateral, multilateral trade and a number of sectors is Vietnam's strength in the context of FTAs such as [13], [27], [28], [45], [42]. Their research results demonstrate how tariff reductions can lead to trade creation or trade diversion; tariff cuts lead to trade diversion from lower cost countries. to higher cost FTA partners. When the export prices of existing trading partners (including tariffs) are higher than those of the higher-cost FTA countries, this diversion becomes more appropriate. Baier and Bergstrand [7] used the gravity model to test the impact of FTAs on trade flows, in this study the author uses a weighted model. Gravity with fixed effect model (FEM) based on the approach of [35] on a pair of countries to assess the impact of the Vietnam EAEU FTA and the reduction of tariffs on trade between Vietnam and EAEU countries before and after the agreement.

\section{Trade between Vietnam And the EURASIAN ECONOMIC UNION}

The free trade agreement between Vietnam and the Eurasian economic union took effect from October 5, 2016, and will ease market access within the framework of trade between member countries. The Agreement also creates new conditions for economic and trade activities for businesses of the EAEU and Vietnam. For the EAEU, 
this is the first trade agreement with a third country. The selection of Vietnam as the first country in concluding a free trade agreement with EAEU member countries due to a combination of political importance and factors such as trade risks with Vietnam. The main export products of Vietnam and EAEU member countries do not compete with each other on the domestic market of the member states in the agreement. This will facilitate the parties to achieve a balance of interests, which is the basis for the formation of a free trade area. In the period 2012 - 2019, the value of trade turnover between Vietnam and EAEU member countries increased from 2.71 billion USD in 2012 to 4.85 billion USD in 2019 (accounting for $0.94 \%$ of the trade turnover of Vietnam). Vietnam and $0.58 \%$ of the EAEU in 2019), with a growth rate of $44.1 \%$, of which Russia accounted for $90.9 \%$ of the total trade turnover between Vietnam and the EAEU. After a decline during the 1990s, trade relations between Vietnam and the EAEU, including Russia, had a slow recovery and started to increase slightly. After Vietnam and the EAEU negotiated and signed a free trade agreement in 2015, the average growth rate of trade turnover was $15.1 \%$, equivalent to a turnover of 4.15 billion USD compared to 1. $41 \%$ or 2.79 billion USD in the period before and after the agreement. In which, Vietnam's export turnover to the EAEU increased by an average of $2.7 \%$, equivalent to a turnover of US\$ 1.84 billion to $13.7 \%$, equivalent to US\$ 2.42 billion. Men from the EAEU increased on average from $16.2 \%$ or 1.72 billion USD compared to a decrease of $1.16 \%$, equivalent to 948.4 million USD of the period before and after the signing of the agreement.

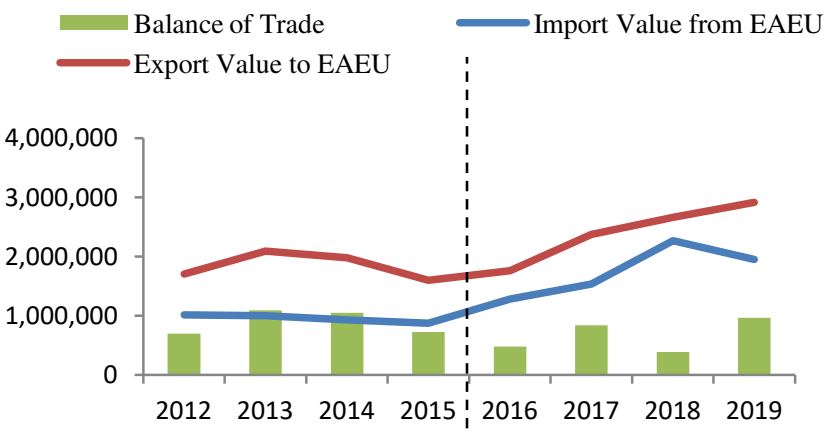

Unit: 1.000 USD

Figure 1. Trade between Vietnam and the Eurasian Economic Union

Source: Author's calculations from ITC datahttp://www.trademap.org

In 2019, export turnover between Vietnam and EAEU increased by $18.6 \%$ and $8.7 \%$ compared to 2017 and 2018 respectively, import turnover increased by $22.7 \%$ compared to 2017 but decreased compared to 2017 with 2018 being $14.9 \%$. According to the Ministry of Industry and Trade (2020), bilateral trade between Vietnam and Eurasian countries is constantly developing, in 2019 twoway trade turnover reached 10.4 billion USD compared to 2018, accounting for 2 billion USD. \% of Vietnam's total trade turnover with the world, of which trade turnover between Vietnam and the Eurasian economic union reached US\$4.85 billion, accounting for $46.6 \%$. Vietnam's import-export turnover is still very modest compared to the total trade turnover of about 1.4 trillion USD, equivalent to $0.5 \%$ market share, of countries in this region. In the context of the implementation of the Vietnam - EAEU FTA, making effective use of this FTA will be the driving force to further promote trade, industrial and investment cooperation between Vietnam and EAEU countries.

\section{MODEL AND METHODOLOGY}

In Tinbergen's [39] basic model for trade between two countries ( $\mathrm{i}$ and $\mathrm{j}$ ), where $\mathrm{F}$ flows between the two countries (gravity), $\mathrm{M}$ is the size of the economy (measurement of equal to GDP or GNP) of each country, $\mathrm{D}$ is the distance between the two countries, $\mathrm{G}$ is a constant, expressed as follows:

$$
F_{i j}=G \frac{M_{i} M_{j}}{D_{i j}}
$$

To measure the distance between two countries, the studies use trade cost measures. [16], [2], [12] has measured the cost of trade by using variables such as the border effect in trade. The authors have shown that the cost of bilateral trade between two countries is affected by the cost of bilateral trade and the level of multilateral resistance. [2] pointed out that the multimodal resistance factors need to be empirically studied to avoid a biased estimate of the parameters in the model. Similarly, Matyas [24] suggested that bilateral trade flows should be estimated in three ways including time effects, fixed effects of exports and imports to avoid inconsistent model results caused by missing variables or unobserved variables. As time-varying multilateral resistance factors, [7] found that time-invariant fixed effects were insufficient to know the observations in the gravity model. They [7] followed the methods of [2] and extended the data series from cross-sectional to panel data to estimate time-fixed effects. To eliminate endogenous variables in the model derived from the FTA dummy, Baier and Bergstrand [7] used country-pair fixed effects in addition to the effects mentioned above to estimate the variable cost of trade. time to obtain unbiased estimates.

From studies on the impact of FTAs, in this study the author uses the model of [2]:

$$
F_{i j}=\frac{Y_{i} Y_{j}}{Y_{W}}\left(\frac{T_{i j}}{P_{i} P_{j}}\right)^{1-\sigma}
$$

Where $F_{i j}$ is the trade volume between country $\mathrm{i}$ and country j. $Y_{i}, Y_{j}$ and $Y_{w}$ are the GDP of country $\mathrm{i}, \mathrm{j}$ and world, respectively. The cost of trade between two countries is $T_{i j}$. $P_{i}, P_{j}$ is the country's overall equilibrium price index $\mathrm{i}$ and $\mathrm{j}$. And $\sigma>1$ is the elasticity of substitution for all goods, showing that the cost of trade between two countries will have a negative effect on bilateral trade. However, based on previous empirical studies, it is not possible to collect aggregate equilibrium price index data $P_{i}, P_{j}$, so this study will consider these price indexes to be a random effect. random effects in the model. 
From the general gravity model (2), the trade between countries $\mathrm{i}$ and $\mathrm{j}$ can be expressed as follows:

$$
X_{i j t}=\alpha Y_{k t}^{\beta 1} Y_{l t}^{\beta 2} D_{I S T}^{\beta_{3 l}} F_{h k l}^{\varnothing k} \mu_{k l t}
$$

Where $X_{i j t}$ is the trade flow or import-export turnover from country $\mathrm{k}$ to country 1 in year t. $Y_{k t}$ is the GDP of country $\mathrm{k}$ in year $\mathrm{t}, Y_{l t}$ is the GDP of country $\mathrm{k}$ in year $t$ to country 1 in year $t, P O P_{k l t}$ is the population of country k, 1 in year t, $D I S T_{k l}$ is the geographical distance between 2 countries $\mathrm{k}$ and $1, F_{\text {hklt }}$ are other factors such as population, per capita income, exchange rate, tariffs and FTAs, etc. that can promote or restrict trade flows, $\square_{k l t}$ is a random variable

The gravity model formulated by [39] has been used by many studies, but lacking theoretical justification, studies have attempted to develop the economic theory of the gravity model. Further studies have extended the basic gravity model and added some suitable variables. Linnemann [21] added population as a proxy for market size, [34] measured the impact of exchange rate fluctuations. [22], [16] and [48] found the effect of average tariffs on bilateral trade. To assess the impact of the Vietnam - EAEU FTA on trade between Vietnam and EAEU countries through export and import turnover, the article selects a structural gravity model to analyze the impact of the FTA and economic factors affecting trade between two parties such as the study of [2], [30]. From equation (3) take the logarithm and rewrite it as follows:

$$
\begin{aligned}
& E X_{k l t}=\beta_{0}+\beta_{1} \ln \ln \left(G D P_{V N t} * G D P_{l t}\right)+\beta_{2} \\
& \ln \ln \left(P O P_{V N t} * P O P_{l t}\right)+\beta_{3} \ln \ln I N C G A P_{V N l t}+\beta_{4} \\
& \ln l n D I S T_{V N l t}+\beta_{5} F T A_{-} E A E U_{k l}+\beta_{6} L n T A R_{k l t}+ \\
& \beta_{7} \operatorname{LnREER_{VNlt}}+\varepsilon_{\text {klt }} \\
& I X_{k l t}=\beta_{0}+\beta_{1} \ln \ln \left(G D P_{V N t} * G D P_{l t}\right)+\beta_{2} \\
& \ln \ln \left(P O P_{V N t} * P O P_{l t}\right)+\beta_{3} \ln \ln I N C G A P_{V N l t}+\beta_{4} \\
& \ln \text { ln DIST } T_{V N l}+\beta_{5} F T A_{-} E A E U_{k l}+\beta_{6} L n T A R_{k l t}+ \\
& \beta_{7} \operatorname{LnREER_{VNlt}}+\varepsilon_{k l t}
\end{aligned}
$$

Where:

Index $\mathrm{k}$ is of industry $\mathrm{k}$.

1 is the index of country 1 .

$\mathrm{t}$ is the time

$E X_{k l t}$ is the export turnover of industry $\mathrm{k}$ from Vietnam to country 1 in the year $\mathrm{t}$.

$I X_{k l t}$ is the import turnover of industry $\mathrm{k}$ of Vietnam from country 1 in year $\mathrm{t}$.

$G D P_{V N t}$ and $G D P_{l t}$ is the gross domestic product of Vietnam to country 1 in year $\mathrm{t}$.

$P O P_{V N t}$ and $P O P_{l t}$ are the populations of Vietnam and country 1 in year $\mathrm{t}$.

ln INCGAP $P_{V N l t}$ is the income difference per capita between Vietnam and its trading partners 1 .

$\operatorname{lnDIST}_{V N l}$ is the distance from Vietnam to country 1.

$R E E R_{V N l t}$ is the exchange rate the actual exchange rate between Vietnam and country 1 at time t.

$T A R_{k l t}$ is the tax rate of Vietnam applied to goods imported/exported from country 1 for goods $\mathrm{k}$ at time $\mathrm{t}$.
$F T A_{-} E A E U_{k l}$ is a dummy variable, measuring the impact of FTAs on exports and imports, takes the value equal to 1 if Vietnam and the EAEU have signed the agreement and comes into force, the value 0 otherwise.

For zero trade issue: A problem that has been recently discussed by many researchers in gravity modeling is how to deal with the "0s" in the dependent variable, specifically in bilateral trade between a given pair of countries. Statistical "0" values in trade can occur for a number of reasons such as: (i) rounding errors due to missing observations being incorrectly recorded as "0"; (ii) results of companies deciding not to export to a certain point, especially when dealing with trade data by industry, ect. To solve this problem, several methods have been tried such as: (1) convert the original model to a Log-Log model, trade flows with " 0 " or missing data will be excluded from the model's estimate; (2) Pseudo Poisson maximum probability estimate (PPML) proposed by Santos Silva and Fenreyro (2011). Assuming that the numbers "0" are the result of rounding errors and that the missing observations are misreported as " 0 ", this approach however does not provide a truly accurate result; (3) implement the method of testing the two-step estimator Heckman model proposed by Helpman, including: Step 1, perform a probability regression model (probit) so that the import-export is positive. Step 2, perform regression estimation on positive import and export turnover based on 2 regression tools: (i) correction for selection bias, (ii) correction for heterogeneity of variables. The disadvantage of the model is that it is difficult to find the exclusion variable for the exogenous Probit model with commercial value and to keep

In the table data, the value " 0 " appears, according to the observed statistics collected, it is shown that in the list of imported or exported product codes, Vietnam does not always export or import all the products. the product to the EAEU countries. Therefore, to reduce the problem of trade to zero, the author builds the data instead of the product level, which is moved to the industry level. Vietnam's trade statistics with the EAEU are not evenly distributed by product level and by industry, so the study uses unbalanced tabular data.

In order to know the heterogeneity of all timeinvariant and time-varying unobserved variables among trading partners, the indicative model form was estimated unbiased and consistent. First, we estimate equations (4), (5) by pooled OLS technique and remove individual country and time dummy variables from the model. The OLS estimate merely aggregates all available data, but it does not reveal differences between individual pairs of trading countries. To clarify the difference between countries in trade exchange, the author will estimate the above equation according to fixed effect method (FEM) and random effect method (REM). According to [14], the random effects model (REM) is more appropriate when estimating trade flows between randomly sampled samples of trading partners from a larger population. However, a fixed effect model (FEM) would be a better choice than REM when one is interested in estimating trade flows between predefined choices of countries. Since the sample of the study includes only the value of trade between Vietnam and the five EAEU countries, FEM is 
likely the best estimate [7]. To determine whether the format of the estimation method is a fixed-effects model (FEM) or a random-effects model (REM), the author uses the Hausman Test to determine. In addition, the author will also estimate the model with strong variance selection (robust) to get better estimation results.

\section{RESULTS AND DISCUSSION}

\section{A. Descriptive statistics}

The trade data collected in this study is secondary data under the 2-digit industry code (HS2) between Vietnam and the EAEU countries (including Armenia, Belarus, Kazakhstan, Kyrgystan and Russia). The research data used are tabular data for goods classified by international and Vietnamese industry codes from code 1 to code 99 (from HS code to ISIC code). Trade data collected for 19 years (from 2001 to 2019) is used for quantitative model estimation, in which there are countries related to import and export of industries and there are countries that are not related, so the number of observations obtained is 5,386 observations forming an unbalanced repeating pattern. The total number of observations included in the quantitative research model is 5,386 observations. Data on import and export turnover, gross national income (GDP), per capita income, population, distance, tariffs and exchange rates are collected from the UNCTAD statistical database, WB Indicators, CEPII, WITS and Brugel, FTA data from WTO center of Vietnam Chamber of Commerce and Industry (https://trungtamwto.vn/fta/174-da-ky-ket/1).

TABLE 1. DESCRIPTIVE STATISTICS OF THE VARIABLES IN

\begin{tabular}{|l|l|l|l|l|l|}
\multicolumn{7}{c}{ THE MODEL } \\
\hline Variables & Obs. & $\begin{array}{l}\text { Mea } \\
\text { n }\end{array}$ & Std. & Min & Max \\
\hline Inex & 5,38 & 18.1 & 1.9 & 12.7 & 20.0 \\
& 6 & 5 & 0 & 2 & 8 \\
\hline $\operatorname{lnim}$ & 5,38 & 17.8 & 1.4 & 13.2 & 19.5 \\
& 6 & 9 & 3 & 7 & 7 \\
\hline In(GDPVNt, *GDPjt) & 5,38 & 51.7 & 2.1 & 45.4 & 54.4 \\
& 6 & 2 & 5 & 8 & 5 \\
\hline In(POPVNt, *POPjt) & 5,38 & 35.8 & 1.4 & 33.1 & 37.1 \\
& 6 & 4 & 8 & 4 & 7 \\
\hline lnincgap & 5,38 & -1.57 & 0.5 & -2.31 & 0.67 \\
& 6 & & 0 & & \\
\hline Indist & 5,38 & 8.77 & 0.1 & 8.20 & 8.91 \\
& 6 & & 9 & & \\
\hline Inreer & 5,38 & 6.81 & 2.1 & 3.28 & 11.5 \\
& 6 & & 4 & & 7 \\
\hline Intarsimp & 5,38 & 1.91 & 1.2 & -3.91 & 4.81 \\
& 6 & & 2 & & \\
\hline FTA_EAEU & 5,38 & 0.32 & 0.4 & 0.00 & 1.00 \\
& 6 & & 7 & & \\
\hline
\end{tabular}

Source: Author's compilation from Stata 15.0 software

\section{B. Regression analysis}

Estimation results of structural gravity model (4), (5) with panel data are presented in Table 2 by fixed effect estimation method (FEM), and performed to estimate the corresponding strong variance (robust) in column (2). In which, columns (1) and (2) present the results of estimating the export and import equations in order to measure the impact of the agreement and the factors on Vietnam's import and export with countries in the EAEU. The author performed a Hausman test (Hausman test) to choose between FEM and REM models for the import- export equation, the results show that Prob>chi2 are both less than 5\%. Thus, the fixed-effects model (FEM) is suitable. At the same time, the author also conducted Wald test to show that Prob>chi2 is less than 5\%, the model has variable variance phenomenon. To overcome this, the study performed estimation with strong variance (robust) to get better estimation results.

TABLE 2. MODEL ESTIMATION RESULTS BY FIXED EFFECTS METHOD (FEM), LOGARITHMIC DEPENDENT VARIABLE OF EXPORT AND IMPORT

\begin{tabular}{|c|c|c|c|c|}
\hline \multirow[b]{2}{*}{$\begin{array}{l}\text { Independent } \\
\text { variables }\end{array}$} & \multicolumn{2}{|c|}{ Lnex } & \multicolumn{2}{|c|}{ Lnim } \\
\hline & $\begin{array}{l}\text { FEM } \\
(1)\end{array}$ & $\begin{array}{c}\text { FEM } \\
\text { (robust) } \\
(2)\end{array}$ & $\begin{array}{c}\text { FEM } \\
(1)\end{array}$ & $\begin{array}{c}\text { FEM } \\
\text { (robust) } \\
(2)\end{array}$ \\
\hline \multirow{2}{*}{$\begin{array}{l}\ln \left(\mathrm{GDPVNt},{ }^{*} \mathrm{G}\right. \\
\mathrm{DPjt})\end{array}$} & $\begin{array}{r}0.488 * * \\
*\end{array}$ & $0.488 * * *$ & $\begin{array}{r}0.375^{* *} \\
*\end{array}$ & $0.375^{* * * *}$ \\
\hline & $(0.002)$ & $(0.002)$ & $(0.003)$ & $(0.004)$ \\
\hline \multirow{2}{*}{$\begin{array}{l}\ln \left(\mathrm{POPVNt},{ }^{* P}\right. \\
\text { OPjt) }\end{array}$} & $\begin{array}{r}0.190 \text { ** } \\
*\end{array}$ & 0.190 **** & $\begin{array}{r}0.671 * * \\
*\end{array}$ & $0.671^{* * *}$ \\
\hline & $(0.002)$ & $(0.002)$ & $(0.004)$ & $(0.005)$ \\
\hline \multirow[t]{2}{*}{ lnincgap } & $\begin{array}{r}- \\
0.443^{* *} \\
*\end{array}$ & $-0.443 * * *$ & $\begin{array}{r}- \\
0.692^{* *} \\
*\end{array}$ & $-0.692 * * *$ \\
\hline & $(0.008)$ & $(0.013)$ & $(0.014)$ & $(0.027)$ \\
\hline \multirow[t]{2}{*}{ lndist } & $\begin{array}{r}0.103 * * \\
*\end{array}$ & $-0.103^{* * * *}$ & $\begin{array}{r}1.148^{* *} \\
*\end{array}$ & $-1.148 * * *$ \\
\hline & $(0.012)$ & $(0.020)$ & $(0.021)$ & $(0.030)$ \\
\hline \multirow{2}{*}{ FTA_EAEU } & $\begin{array}{r}0.018 \text { ** } \\
*\end{array}$ & $0.018^{* *}$ & $\begin{array}{r}0.211 * * \\
*\end{array}$ & $0.211^{* * *}$ \\
\hline & (0.007) & $(0.008)$ & $(0.011)$ & $(0.016)$ \\
\hline \multirow[t]{2}{*}{ lntarsimp } & $\begin{array}{r}- \\
0.009 * * \\
*\end{array}$ & $-0.009 * * *$ & $\begin{array}{r}- \\
0.013^{* *} \\
*\end{array}$ & $-0.013 * *$ \\
\hline & $(0.002)$ & $(0.003)$ & $(0.004)$ & $(0.005)$ \\
\hline \multirow{2}{*}{ Inreer } & $\begin{array}{r}0.129 * * \\
*\end{array}$ & $0.129 * * *$ & $\begin{array}{r}0.221 * * \\
*\end{array}$ & $0.221 * * *$ \\
\hline & $(0.001)$ & $(0.001)$ & $(0.002)$ & $(0.002)$ \\
\hline \multirow[t]{2}{*}{ Constant } & $\begin{array}{r}16.593^{*} \\
* *\end{array}$ & $16.593 * * *$ & $\begin{array}{r}17.868^{*} \\
* *\end{array}$ & $17.868^{* * *} *$ \\
\hline & $(0.100)$ & $(0.183)$ & $(0.172)$ & $(0.270)$ \\
\hline \multicolumn{5}{|l|}{ Hausman Test } \\
\hline Chi2 & 29.53 & & 31.86 & \\
\hline Prob>chi2 & 0.0001 & & 0.000 & \\
\hline \multicolumn{5}{|l|}{ Wald test } \\
\hline Chi2 (212) & $7.1 \mathrm{e}+28$ & & 230,000 & \\
\hline Prob $>$ chi 2 & 0.0000 & & 0.000 & \\
\hline Observations & 4,230 & 4,230 & 4,230 & 4,230 \\
\hline R-squared & 0.995 & 0.995 & 0.992 & 0.992 \\
\hline $\begin{array}{l}\text { Number of } \\
\text { products }\end{array}$ & 212 & 212 & 212 & 212 \\
\hline
\end{tabular}

Source: Author's compilation from Stata 15.0 software

Note: Standard errors in parentheses ( $p$-values in parentheses): * $p<.1$, $* * p<.05$, *** $p<.01$, expressed at the 10\%, 5\% and $1 \%$ significance level, respectively

The estimated results are statistically significant and consistent with the hypotheses of the gravity model, the 
model's R-squared index shows that it can explain the relationship between Vietnam's exports and imports with EAEU countries are $99.5 \%$ and $99.2 \%$ respectively, this relationship is similar to previous studies [22], [16], [2].

The coefficients of the explanatory variables in column (2) have similar results with column (1). In the two columns of the model results, the agreement has a positive impact on Vietnam's imports and exports to EAEU countries, increasing by $0.018 \%$ and $0.021 \%$ respectively compared to before the agreement. This result is also consistent with the predictions when Vietnam and the EAEU signed a free trade agreement to facilitate increased trade between the two sides, which also helped Vietnam to expand and access the EAEU market. The analysis of the effect of the agreement on the trade of member countries is also consistent with previous studies [2], [7], [15], [4].

In addition, according to the gravity model's hypothesis, distance is negatively related to trade flows between the two sides [39], [1], [2], [7], previous studies estimated the elasticity of trade by distance between -0.42 and -1.4. However, the coefficient of the distance variable depending on the country or a group of countries is the focus in particular studies. In this study, the coefficient of the distance variable between Vietnam and its EAEU partners is - 0.103 and - 1.148 and has statistical significance at $1 \%$, showing that distance has an inverse relationship and has a positive effect. negative impact on Vietnam's import and export to the countries in the agreement. For variables of economy size (GDP), population (POP) of Vietnam and partner countries have a positive impact on Vietnam's exports. Specifically, with the statistical significance level of $1 \%$ of the variables of economic size and population, there is a positive correlation between Vietnam and the countries in the agreement.

The economic growth (GDP) of both Vietnam and the partner country increases Vietnam's exports to the partner country. This is completely consistent with international trade theory and gravity model related to economic growth, market access and size of partner market when participating in trade agreements. international.

For the variable of income per capita of Vietnam compared with partner countries, although it is statistically significant at $1 \%$, the coefficient of this variable is -0.44 and -0.69 has a correlation. inversely related to the import and export turnover of Vietnam with the countries in the agreement. This shows that Vietnam is a middle-income country, lower than EAEU countries, so the level of economic development is still low, the level of specialization and labor productivity in industries in the economy is still low. low affects the import and export turnover of Vietnam in general.

The variables related to the factors of attractiveness or trade barriers including the variable tariff (tarsimp) and the exchange rate (reer) are statistically significant at $1 \%$, the coefficient of the tarsimp variable is negatively correlated. With export turnover, it shows that a $1 \%$ tariff reduction according to the agreement's roadmap will increase Vietnam's export and import turnover to the countries in the agreement, which is also consistent with other studies. earlier by [22], [16], [4] on the relationship of tariff liberalization leading to higher trade flows. When EAEU countries cut $1 \%$ tariffs on goods imported from Vietnam, it will make Vietnam's exports to the EAEU market $0.09 \%$ and imports increase $0.013 \%$. Thus, it can be seen that the tariff reduction has increased Vietnam's imports and exports, but this increase is relatively low compared to other FTAs such as the EVFTA and CPTPP, the reduction of $1 \%$ of tariffs in each period. The agreement will increase Vietnam's exports to member countries by $1.69 \%$ and $0.016 \%$, respectively [45], [46].

For the exchange rate variable (reer), the coefficient has a positive, which shows that Vietnam's stable exchange rate policy creates favorable conditions to promote exports to partner countries.

\section{CONCLUSION}

The Vietnam - EAEU FTA is one of the important factors promoting trade in goods between Vietnam and the countries in the agreement. Import and export turnover between Vietnam and EAEU tends to increase after the agreement comes into effect in 2016, the average growth rate in the period after the agreement comes into force is higher than in the previous period, Vietnam's exports to the EAEU increased by $0.018 \%$ and imports from the EAEU increased by $0.021 \%$ compared to before the FTA. At the same time, the tariff reduction under the agreement also had a positive effect, specifically, reducing the tariff by $1 \%$ made Vietnam's exports to the countries in the agreement and EAEU increased by $0.009 \%$, while the EAEU increased by $0.009 \%$. With a $1 \%$ tariff reduction, Vietnam's imports from the EAEU and Russia are $0.013 \%$ respectively. Thus, it can be seen that the tariff reduction according to the roadmap of the agreement until 2019 has increased import and export or "created trade" between Vietnam and countries in the Eurasian economic union (EAEU).

Vietnam and EAEU countries need to take measures to promote bilateral trade within the framework of the Vietnam - EAEU free trade agreement. Up to now, this agreement has been implemented and is in the process of reducing tariff barriers, non-tariff barriers have contributed to increasing bilateral trade turnover in recent years and brought high efficiency. However, it is still not commensurate with the potential of cooperation between the two sides. Therefore, Vietnam and the EAEU countries continue to remove difficulties and facilitate trade, implement the roadmap according to commitments as well as adjust policies in line with the economic political situation in the context of the current situation. new in the region and the world. At the same time, the two sides need to step up the production and export of products with comparative advantage in order to enjoy the incentives from the agreement. influence competition and complement each other to increase "trade creation". Vietnam needs to increase its scale and specialize in the production of products with comparative advantages such as textiles and garments, footwear, bags, seafood and wooden furniture, high-quality agricultural products, these are consumer products that the market cannot afford. EAEU schools are in great demand. In addition, the Vietnam - EAEU FTA has created a large and highly 
liberalized market in trade exchange between the two sides, so Vietnam and EAEU countries need to have specific policies and regulations related to the trade. In particular, it is necessary to consider recognizing the conversion between the ruble and the Vietnamese dong as well as stabilizing the exchange rate in order to limit risks and promote trade exchange between Vietnam and EAEU countries. At the same time, Vietnam and the member countries of the Eurasian economic union further accelerated the process of reducing administrative tariffs and non-tariff barriers (tariff and non-tariff quotas), threshold safeguard) for goods and products in which the two sides have competitive advantages. Improve the competitiveness of Vietnamese goods when implementing the Vietnam - EAEU FTA by identifying advantageous and attractive products, creating favorable conditions for enterprises to invest in production. In international trade, both relative advantage, absolute advantage and competitive advantage must be considered. In regional and global production value chains, goods include not only end products, but also inputs, components and intermediate products. Thus, it can be affirmed that this agreement and the reduction of tariffs have a positive impact on the trade of the two sides.

\section{REFERENCES}

[1] Anderson, J. (1978), A Theoretical Foundation for the Gravity Model of Factor Flows (No. 85), Boston College Department of Economics.

[2] Anderson, J.E., and Van Wincoop. E. (2003), Gravity with gravitas: A solution to the border puzzle, American Economic Review, 93(1), pp $170-192$.

[3] Athukorala, P.C. (2006), Trade policy reforms and the structure of protection in Vietnam, World Economy, 29(2), pp. $161-187$.

[4] Adarov, A. and Ghodsi, M. (2020), The impact of the EAEU - Iran preferential Trade Agreement, Working Paper 179, The Vienna Institute for International Economic Studies.

[5] Bhagwati, J. and Srivinivasan, T.N. (2002), Trade and poverty in the poor countries, American Economic Review, No92(2), 180 - 183.

[6] Berg, M.A. \& Krueger, A.O. (2003), Trade, growth and property: A selective survey, International Monetary Fund.

[7] Baier, S.L. \& Bergstrand, J.H. (2009), Do Free Trade Agreements Actually Increase Members' International trade?, Journal of International Economics, Vol.71, pp. 72-95.

[8] Baldwin, R., and Taglioni, D. (2006), Gravity for dummies and dummies for gravity equations, National Bureau of Economic Research Working Paper No. 12516.

[9] Carrere C. (2006), Revisiting the effect of regional trading agreements on trade flows with proper specification of the Gravity model, European Economic Review, No.50, pp.223 - 247.

[10]Cassing, J., Trewin, R., Vanzetti, D., Truong Dinh Tuyen, Nguyen Anh Duong, Le Quang Lan, Le Trieu Dung (2010), Impact assessment of Free Trade Agreement on Vietnam's Economy, MUTRAP

[11]Diao, X. \& Somwaru, A. (2000), A Dynamic Evaluation of the Effects of A Free Trade Area of the Americas - An Intertemporal, Global General Equilibrium Model, Journal of Economic Integration, Vol. 16, No1, pp. $21-47$.

[12]Deardoff, A. V. (2004), Local Comparative Advantage: Trade Costs and the Pattern of Trade, University of Michigan Research Seminar in International Economics, Working Paper No. 500

[13]Do, Tri Thai (2006), A gravity model for trade between Vietnam \& twenty - three European countries, Doctor Department of Economics \& Soceity, Dalarne University.

[14]Egger P. (2000), A Note on the Proper Econometric Specification of the Gravity Equation, Economics Letters Vol. 66 (1), pp.25-31.

[15] Evans D., M. Gasiorek, A. Ghoneim, P. M. Haynes, P. Holmes, L. Iacovone, K. Jackson, S. Iwanow, S Robinson and J. Rollo (2006), Assessing regional trade agreements with developing countries:
Shallow and Deep Integration, Trade, Productivity, and Economic Performance, University of Sussex Press, United Kingdom

[16]Feenstra, R.C. (2002), Border Effects and the Gravity Equation: Consistent Methods for Estimation, Scottish Journal of Political Economy, Volume 49, Issue 5, pp. 491 - 506.

[17]Fukao, K. Okubo, T. and Stern, R. M. (2003), An Econometric Analysis of Trade Diversion under NAFTA, Research Seminar in International Economics, The University of Michigan, Discussion Paper No.491

[18]Fedorov, N.V. (2018), The free trade agreement between the EAEU and Vietnam as a factor of Russia - Vietnamese relations, Comparative Politics Russia, No. 1, pp. 74-90.

[19]Krueger, A.O. (1997), Free Trade Agreements versus Customs Unions, Journal of Deveplopment Economics, 54(1), pp $169-187$.

[20] Krugman, P.R. (2009), International Economics: Theory and Policy, 8/E: Pearson Education India.

[21]Linnermann, H. (1966), An Econometric Study of International Trade Flows, North - Holland Publishing, Nertherland.

[22]Learner, E.E. (1988), Cross - section estimation of the effect of trade barriers, in Feenstra, R. (Ed): Emperical Methods for International Trade, The MIT Press, Cambridge.

[23]Leke, S.K. (2012), Economic integration and the internal governance of member states: A case study of CEMAC and Cameroon, University of Witwatersrand, Johannesburg, South Africa.

[24]Matyas, L., (1998), The gravity model: Some econometric considerations, The World Economy, 21 (3), pp. 397 - 401.

[25] Martínez-Zarzoso, I., Nowak-Lehmann, D. F. and Horsewood, N. (2009), Are Regional Trading Agreements Beneficial? Static and Dynamic Panel Gravity Models, North American Journal of Economics and Finance, Vol. 20 (1), pp. 46-65.

[26]MacMillan, M., Rodrik, D. \& Verduzco - Gallo, I. (2014), Globalization, structural change, and productivity growth, with an update on Africa, World Development, Vol. 63 (1), pp 11 - 32.

[27]Nguyễn Tiến Dũng (2011), Tác động của khu vực thương mại tự do ASEAN - Hàn Quốc đến thương mại Việt Nam, Tạp chí Khoa học ĐHQG Hà Nội, Kinh tế and Kinh doanh, số 27, trang 219 - 331

[28] Nguyen Hai Tho (2013), Determinants of Vietnam's exports: A gravity Model approach, Master of Science in Finance and Economics, Martin De Tours School of Managment and Economics.

[29]Hapsari, I.M and Mangunsong, C. (2006), Determinants of AFTA Members' Trade Flows and Potential for Trade Diversion, Working Paper Series, No. 21, Asia-Pacific Research and Training Network on Trade (ARTNeT), Bangkok.

[30]Head, K. and Mayer, T. (2014), Gravity equations: Workhorse, Toolkit and Cookbook, In handbook of International Economics, Vol.4, pp. 131 - 195, Elsevier

[31] Poyhonen (1963), P., A Tentative Model for the Volume of Trade Between Countries, Welwirtschaftliches Archiv 90, No 1, pp. 93 100.

[32]Plummer, M. G., Cheong, D., and Hamanaka, S. (2010), Methodology for Impact Assessment of Free Trade Agreements, Asian Development Bank (ADB).

[33]Riedel, J. (1997), The Vietnamese economy in the 1990s, Asia Pacific Economic Literature, 11(2), pp. 58 - 65.

[34]Rojid, S. (2006), Comesa Trade Potential: A Gravity Approach, Applied Economics Letters, Vol.13, No.14, pp. 947 - 951.

[35] Romalis, J., (2007), NAFTA's and CUSFTA's impact on international trade, The Review of Economics and Statistics (2007) 89 (3): pp.416-435.

[36] Ramstetter, E.D. \& Phan, N.M. (2013), Productivity, ownership, and producer conectration in transition: Futher evidence from Vietnamese manufaturing, Journal of Asia Economics, No 25, pp. 28 $-42$.

[37] Santos - Paulino, A. \& Thirlwall, A.P. (2004), The impact of trade liberalization on export, imports and the balance of payments of developing countries, The Economic Journal, 114 (493), 50 - 72.

[38] Santos Silva, J.M.C., Tenreyo, S. (2011), Further simulation evidence on the performance of the poisson pseudo-maximum likelihood estimator, Economic Letters, Vol. 112, pp. 220-222.

[39] Tinbergen (1962), J., Shaping the World Economy: Suggestions for an International Economy Policy, The Tweentieth Century Fund, New York.

[40] Trần Văn Thọ (2002), AFTA in the Dynamic Perspective of Asia Trade, Jcer Discussion Paper No 77, Japan Center for Economic Research. 
[41] Tran, K.N. \& Heo, Y. (2009), Impact of trade liberlization on employment in Vietnam: A system generalized method of moments estimation, The Developing Economies, 47(1), 81 - 103.

[42] Thu, L.A, Fang, S. and Kessani, S.S (2019), Factors influencing Vietnam's handicraft export with the gravity model, Journal of Economics and Development, Vol.21, No.2, pp. $156-171$.

[43] Viner, J. (1950), The Customs Union Issue, New York: Carnegie Endowment for International Peace.

[44] Vanzetti, D. and Pham, H.L (2006), Vietnam's Trade Policy Dilemmas, Paper preseted at the The Ninth Annual Conference on Global Economic Analysis, Addis Ababa, Ethiopia

[45] Vũ Thanh Hương (2017), Hiệp định thương mại tự do Việt Nam - EU: Tác động đối với thương mại giữa hai bên và hàm ý cho Việt Nam
(Vietnam-EU Free Trade Agreement: Implications for two sides trade and effects for Vietnam). Luận án tiến sĩ kinh tế, Trường Đại học Kinh tế, ĐHQG - Hà Nội.

[46] Van Su Ha and Hoi Le Quoc (2019), The impact of participation in the comprehensive and progressive trans - pacific partnership agreement on exports: The case of Vietnam, Management Science Letters, Vol.9, pp. 1269 - 1280.

[47] Urata Shujiro and Okabe Misa (2007), The impacts of free trade agreements on trade flows: An application of the gravity model approach, RIETI Discussion paper series $07-\mathrm{E}-052$.

[48] Wang, Q. (2001), Import - Reducing Effect of Trade Barriers: A cross - Country Investigation, IMF Working Paper, No. 1/216. Địa chỉ: https://papers.ssrn.com/sol3/papers.cfm?abstract_id=880899 [Truy cập ngày 15/04/2019]. 